\title{
Determination of the plasmid size and location of $\delta$ - endotoxin genes of Bacillus thuringiensis by pulse field gel electrophoresis
}

\author{
Roderick L. Rolle*, Anthony O. Ejiofor, Terrance L. Johnson \\ Biological Science Department, Tennessee State University 3500 John A. Merritt Blvd. Nashville, TN. 37209-1561 ${ }^{\text {a }}$ \\ Accepted 16 May, 2005
}

\begin{abstract}
The genes encoding the $\delta$-endotoxins of Bacillus thuringiensis are located on plasmids ranging in size from 45 to $1000 \mathrm{~kb}$. Plasmid size and variety are diagnostic features for characterizing subspecies of this aerobic spore-forming crystalliferous entomopathogen. Two of $25 \mathrm{~B}$. thuringiensis isolates obtained from Middle Tennessee were characterized into subspecies on the basis of size, number, and varieties of plasmids they host using pulse field gel electrophoresis (PFGE). By using specific pulse angle $\left(120^{\circ}\right)$, field strength $(5 \mathrm{~V} / \mathrm{cm})$, pulse time $(26 \mathrm{~h})$, and agarose concentration $(1.2 \%)$ these DNA molecules were separated from other genomic DNA. The purified DNA product the agarose gel was tested for homology to 49 -endotoxin gene using PCR.. The PFGE data for 5 of the 25 isolates collected in Tennessee showed distinct banding patterns. Two of the isolates had only 1 band whereas the others had more than 4 ranging from 45 to $1000 \mathrm{~kb}$ in size. Isolate 6 and 10 both yielded one $49 \mathrm{~kb}$ fragment that contained the cry1A gene.
\end{abstract}

Key words: Bacillus thuringiensis, $\delta$-endotoxin, pulsed-field gel electrophoresis, plasmid.

\section{INTRODUCTION}

Bacillus thuringiensis $(\mathrm{Bt})$ is one of more than 20 species of soil growing Bacilli. This bacterium is a gram positive, aerobic, spore-forming organism. The most discussed of the other species are Bacillus subtilis, a source of industrial enzymes, $B$. thuringiensis, in a lot of cases is confused with Bacillus cereus, and Bacillus anthracis, the causative agent of anthrax. All of these different Bacilli are mostly found in the soil, whereas $B$. thuringiensis has also been sited as been found in living and dead insects, insect feces, granaries, and on the surface of plants (Ohba and Aizawa, 1978). On January 1999 the International Entomopathogenic Bacillus Centre (IEBC) suggested that there are currently $3,493 \mathrm{~B}$. thuringiensis strains grouped into 69 serotypes based on their flagellar $\mathrm{H}$ antigens. More recent studies suggest that these strains are actually 82 serotypes (Lecadet and Frachon, 1999).

\footnotetext{
*Corresponding author. E-Mail: rrolle@mytsu.tnstate.edu.
}

The two most widely used $B$. thuringiensis subspecies in commercial insecticides are $B$. thuringiensis subspecies kurstaki and $B$. thuringiensis subspecies israelensis. B. thuringiensis subsp. kurstaki is used for the control of larval lepidopterans while $B$. thuringiensis subsp. israelensis is used for dipteran larvae control. Further studies of these genes by Höfte and Whiteley (1989) revealed that there needed to be a systematic method of naming these genes. So in 1989 they defined four classes of crystal genes (Cry) and two classes of cytolytic genes (Cyt) that actually produced the toxins that killed these insects. Cryl and Cryll are active against lepidopterans, Cryll and CrylV are active against dipterans, and CryllI is active against coleopterans (Höfte and Whiteley, 1989). The original classification scheme by Höfte and Whiteley was used for several years until the gene number went from 14 to more than 100. A revision of the nomenclature scheme was suggested and accepted because of the large numbers of crystal and cytolytic genes discovered (Crickmore et al., 2002). Roman numerals were replaced with Arabic numbers and each toxin was given four ranks (e.g. Cry50Aa1). The 
quaternary ranking is an optional ranking that is used only to distinguish between toxins that are more than $95 \%$ identical. If the toxin is less than $95 \%$ identical the quaternary ranking will be different (e.g. Cry50Aa2) (Crickmore et al., 2002).

Most subspecies of $B$. thuringiensis have insecticidal activity due to crystal production during sporulation. There are currently 37 families of crystal proteins and 2 families of cytolytic proteins and through cloning and sequencing technology, over 100 genes have been revealed from the crystal and cytolytic protein families (Crickmore et al., 2002). These proteins or $\delta$-endotoxin follow the rules of colinearity, which takes place on plasmids of $B$. thuringiensis (Whalon and McGaughey, 1998). Some of these $\delta$-endotoxins are not just formed by one gene, but some actually form from several genes within an operon. The structure of cry $1 \mathrm{Aa}$ (Grochulski et al., 1995) and cry3A (Li et al., 1991) were determined by $X$-ray crystallography. Based on these observations cry1Aa and cry3A both consist of three domains, each domain being its own polypeptide.

Most of the crystal genes discovered have been linked to movable plasmids, which are extra-chromosomal DNA (Gonzalez et al., 1981). These plasmids are transferred during conjugation, a form of cell-to-cell contact where the sharing of genetic information occurs between bacteria. Many of the $B$. thuringiensis subspecies have multiple crystal and cytolytic gene systems that are simultaneously expressed. This multiple expression has one major function, which is to increase the bacteria host killing range. Major populations of Bacillus can be found in places such as insects, leaf surfaces, and soil. Studies by Meadows suggest that $B$. thuringiensis has been more exclusively found in dead insect carcasses and stored product dust, than it was in the soil.

A physical map of 2.4 to $5.7 \mathrm{Mb}$ was determined by constructing the genome size of two $B$. thuringiensis subspecies (Carlson et al., 1994). Besides the circular genomic DNA that all bacteria have, most of the $B$. thuringiensis isolated have several extra-chromosomal elements, which could exist as linear or circular pieces of DNA (Carlson et al., 1994). It is not totally clear if the genomic chromosome itself produces the crystal proteins, but probes for some crystal genes have hybridized to this genomic chromosome (Carlson and Kolsto, 1993).

\section{MATERIALS AND METHOD}

\section{Isolation of $B$. thuringiensis subspecies from soil}

Isolates of $B$. thuringiensis were collected from three habitats in different locations: surface soil from Middle Tennessee, surface soil from Alabama, and granaries in the middle Tennessee area. The soil samples were treated by sodium acetate selective method (Travers et al., 1987). $1 \mathrm{~g}$ of the samples was incubated for $4 \mathrm{~h}$ at $30^{\circ} \mathrm{C}$ with a $250 \mathrm{rpm}$ agitated baffled Erlenmeyer flask containing $20 \mathrm{ml}$ of $0.30 \mathrm{M}$ sodium acetate $(\mathrm{pH} \mathrm{6.8)}$. The sodium acetate suppresses only $B$. thuringiensis spores from germinating. $2 \mathrm{ml}$ of the sample was heated at $80^{\circ} \mathrm{C}$ for 10 min effectively killing everything that germinated. $300 \mu \mathrm{l}$ of the heat treated sample was spread-plated and incubated for $24 \mathrm{~h}$ on an agar plate containing: 3 $\mathrm{g}$ tryptone; $2 \mathrm{~g}$ tryptose; $1.5 \mathrm{~g}$ yeast extract; $0.05 \mathrm{M}$ sodium phosphate $(\mathrm{pH} 6.8) ; 0.005 \mathrm{~g} \mathrm{MnCl}$ and $15 \mathrm{~g}$ agar per liter. Single colonies that grew were picked, stained by the crystal staining technique, and stored for further analysis (Ejiofor and Johnson, 2002).

Only isolates 6 and 10 were used later to determine where the $\delta$ endotoxins were located within the genome. Both isolates were eluted from one gram of soil from the bank of a pond at Eaton Street/Sulfur Creek Road area in Nashville Tennessee.

\section{Plasmid DNA isolation}

Bacterial cells were taken from the stored slant tubes that contained the colonies of interest. These cells were placed in LB broth containing $1 \%$ glucose. The cells were allowed to grow in a $250 \mathrm{ml}$ baffle flask for $8 \mathrm{~h}$ with major agitation. The agitation was done with a Beckman shaker at the speed of $250 \mathrm{rpm}$ that was in an incubator set at $32^{\circ} \mathrm{C}$. Cells were harvested after $8 \mathrm{~h}$ and $50 \mathrm{ml}$ of the cell suspension was centrifuged at $10,000 \mathrm{rpm}$ for $2 \mathrm{~min}$. The brief centrifugation separated the bacterial cell from the LB broth. The pellet containing the cells was washed twice by vortexing with $2 \mathrm{ml}$ of solution I (TES/STE buffer: $0.01 \mathrm{M}$ Tris (pH 8), $0.001 \mathrm{M}$ EDTA, 1 $\mathrm{M} \mathrm{NaCl}$ ). The pellet was resuspended in $2 \mathrm{ml}$ of lysis buffer containing TE (0.025 M Tris ( $\mathrm{pH} 8), 0.01 \mathrm{M}$ EDTA, $25 \%$ sucrose, 4 $\mathrm{mg} / \mathrm{ml}$ lysozyme) and incubated at $37^{\circ} \mathrm{C}$ for $1 \mathrm{~h}$. This step starts digestion of the cell wall. $2 \mu \mathrm{l}$ of solution II $(2 \mathrm{ml}$ of $10 \mathrm{~N} \mathrm{NaOH}, 10$ $\mathrm{ml}$ of $10 \%$ SDS, and $88 \mathrm{ml}$ of deionized water) was then added. SDS is a detergent that assists in the destruction of the cell wall, while the sodium hydroxide raised the $\mathrm{pH}$ of the solution. This brief raise in the $\mathrm{pH}$ denatures the genomic DNA. The cells were gently lysed by inverting the tube five times. The tube was placed on ice for $5 \mathrm{~min}$ to equilibrate for next step. I $\mathrm{ml}$ of $5 \mathrm{M} \mathrm{NaCl}$ was placed in the tube followed by a brief but gentle vortex. The high salt creates a hypertonic environment which precipitates the genomic DNA and proteins leaving the extra-chromosomal DNA suspended in solution. Store the tube on ice for 3 to $5 \mathrm{~min}$. The content is transferred to a polypropylene tube or glass because the addition of harsh chemicals in the next steps will damage most tubes. (Sambrook et al., 1989)

\section{PCR preparation}

Crystal and cytolytic genes were amplified in a $200 \mu$ reaction tube containing $100 \mu \mathrm{l}$ of $200 \mathrm{ng}$ DNA, $10 \mathrm{mM}$ of dNTP mixture, $0.5 \mu \mathrm{M}$ of each of the 49 primer pairs, 1 X PCR buffer plus $\mathrm{Mg}$, and 2.5 units of Taq DNA polymerase. The reaction was carried out using a GeneAmp PCR System 2400 DNA thermal cycler (Perkin-Elmer, Norwalk, CT). There was an initial 4 min of denaturing of the double stranded DNA at $94^{\circ} \mathrm{C}$, followed by 35 cycles of a 1 min denaturing at $94^{\circ} \mathrm{C}, 45 \mathrm{~s}$ annealing at $45^{\circ} \mathrm{C}$, and 2 min extension at $72^{\circ} \mathrm{C}$. The amplified product was automatically held at $4^{\circ} \mathrm{C}$ until ready for electrophoresis.

The banding pattern of amplified product on the agarose gels was viewed using the imaging system Gel Doc 2000'TM of BIO-RAD manufactured in Hercules, California. The size of each fragment was determined using Diversity Database ${ }^{\mathrm{TM}}$, which was one of four programs included in The Discovery Series ${ }^{\mathrm{TM}}$ Fingerprinting Software by BIO-RAD. Chi square values were calculated for all of the genes using the average of 3 separate runs. Values equal or below 3.84 were accepted as true amplified crystal and cytolytic gene product. Values above 3.84 were rejected as artifacts. 
Table 1. Specific primers used for $B$. thuringiensis crystal and cytolytic gene.

\begin{tabular}{|l|l|l|}
\hline \multirow{4}{*}{ Cry1A } & U/19-mer 5' CAAGATGGGCACGCAAGAC 3' & \multirow{2}{*}{522 kb Expected } \\
\cline { 2 - 3 } Cry11 & L/18-mer 5' ACGACCCGGACAGACACG 3' & \\
\cline { 2 - 3 } Cry2A & U/20-mer 5' TTCGAAACCCGCATCTACTC 3' & \multirow{2}{*}{$413 \mathrm{~kb}$ Expected } \\
\cline { 2 - 3 } & L/22-mer 5' TTCATAATTTGGCTGTCCTGTT 3' & \\
\cline { 2 - 3 } Cry25Aa & U/23-mer 5' CTGCAAGCGAATGTAGAAGAGTT 3' & \multirow{2}{*}{$473 \mathrm{~kb}$ Expected } \\
\cline { 2 - 3 } & L/24-mer 5' GCATATAAATTAGCGCCAGAAGAT 3' & \\
\cline { 2 - 3 } & U/22-mer 5' GGGGGATATGTATGATTGTGGA 3' & \multirow{2}{*}{$477 \mathrm{~kb}$ Expected } \\
\cline { 2 - 3 } & L/22-mer 5' GTAACCTGCGGAGATGATGAAC 3' & \\
\hline
\end{tabular}

The product of amplification was electrophoresed in Tris-AcetateEDTA buffer (TAE) in a $2 \%$ agarose gel at $70 \mathrm{~V}$ and stained with 50 $\mu \mathrm{g} / \mathrm{ml}$ of ethidium bromide. A 50-bp DNA ladder (Gibco BRL) was used to determine DNA fragment size.

\section{PFGE}

Bacterial cells were suspended in $2 \mathrm{ml}$ of cell suspension buffer containing: $1 \mathrm{M} \mathrm{NaCl}, 10 \mathrm{mM}$ Tris $-\mathrm{HCl}(\mathrm{pH} \mathrm{7.6)}$ to an optical density of 1.3 to 1.5 at $450 \mathrm{~nm}$. This suspension was then mixed with equal volume of $2 \%$ low-melting-point InCert $\AA$ agarose by CAMBREX, which made several $100 \mu$ l plugs with dimensions $10 \mathrm{~mm} \times 5 \mathrm{~mm} \times$ $1.5 \mathrm{~mm}$. To help solidify plugs, the casting tray was placed on ice for $10 \mathrm{~min}$. The plugs were then lysed at $37^{\circ} \mathrm{C}$ for $3 \mathrm{~h}$ by submerging them in a lysis buffer containing: $1 \mathrm{M} \mathrm{NaCl}, 100 \mathrm{mM}$ EDTA, 6 mM Tris- $\mathrm{HCl}, 0.5 \%$ Brij 58, $0.5 \%$ deoxycholate, $0.5 \% \mathrm{~N}$ lauroyl sarcosine ( $\mathrm{pH} 7.6), 1 \mathrm{mg}$ of lysozyme/ml and $50 \mu \mathrm{g}$ RNase $\mathrm{A} / \mathrm{ml}$. The plugs were finally incubated overnight at $50^{\circ} \mathrm{C}$ in $2 \mathrm{ml}$ of ESP buffer containing: $0.5 \mathrm{M}$ EDTA, $1 \% \mathrm{~N}$-lauroyl sarcosine $(\mathrm{pH} 8.0$ to 9.3 ), $100 \mu \mathrm{g}$ proteinase $\mathrm{K} / \mathrm{ml}$. After the lyses procedure was complete the cellular debris was washed away by placing the plugs in fresh TE buffer containing 3 times (McEllistrem et al., 2000).

An ultra pure Seakem ${ }^{\circledR}$ Gold agarose was used to make the $1.2 \%$ gels which were used for PFGE. A $0.25 \mathrm{X}$ TBE buffer was used for the circulating buffer and to make the gel. After the $100 \mu \mathrm{l}$ plugs were placed into wells of the agarose gel a thin film of InCert® agarose was layered on top to seal in the plugs. The parameters used to extract large bands ranging in size $300-800 \mathrm{~kb}$ were used. The voltage of $5 \mathrm{~V} / \mathrm{cm}$ was applied for $26 \mathrm{~h}$ with a linear ramping factor. A pulse angle of $120^{\circ}$ was used with a pulse time of $1 \mathrm{~s}$ to $100 \mathrm{~s}$ all in a $14^{\circ} \mathrm{C}$ chilled $0.25 X$ TBE buffer. A lambda ladder for size determination by BIO-RAD laboratory was utilized with fragments ranging from 48.5 to $1000 \mathrm{~kb}$.

A sterile scapula was used to cut a $5 \mathrm{~mm} \times 5 \mathrm{~mm}$ thick slice out of the ultra pure Seakem $\AA$ Gold agarose gel which corresponded to the band of interest. DNA was separated from the agarose by utilization of Wizard $\AA$ Plus Minipreps DNA Purification System by Promega. The kit isolates any size plasmid but is most efficient with DNA less than 20,000 bp in size. Even though the bands of interest in this experiment are both larger than the recommended size specified by the kit, the DNA of interest is still eluted but just with low efficiency. The concentration of DNA was obtained by measuring the absorbency of the solution by using the Genesys ${ }^{\mathrm{TM}} 2$ spectrophotometer by Spectronic $\AA^{\circledR}$.

Purified DNA products from the Seakem ${ }^{\circledR}$ Gold agarose gel were tested against only primers that gave positive hits in previous studies perform in our laboratory (Table 1). The concentration of DNA obtained using the spectrophotometer was utilized with a PCR Reagent System by GibcoBRL $®$ to amplify those positive hits. The products were electrophoresed and analyzed on a $2 \%$ agarose gel. The same imaging system used before by BIO-RAD was utilized to view the banding pattern on the agarose gel.

\section{RESULTS}

\section{The origin of isolates}

Of the thousands of colonies formed on the sodium acetate plates 25 isolates had the characteristics of $B$. thuringiensis based on crystal protein production as shown by the crystal stain used in these studies. These isolated were grown in liquid cultures and the plasmid DNA was extracted and PCR analysis performed. The results for 2 of the 25 isolates are listed below in Tables 2 and 3. Preliminary studies were performed using PFGE and 5 isolates out of the 25 appeared to have multiple banding patterns. This suggested that several of the pulsed fragments could be extra-chromosomal fragments within those 5 isolates. Only two of the five, isolate 6 (Bt6) and isolate 10 (Bt10) were chosen for further analysis.

\section{Crystal gene presence for isolate 6}

Analysis of the amplified product was done using the central tendency (mean) values for crystal genes $1 \mathrm{~A}, 2 \mathrm{~A}$, and 25Aa from isolate 6 . The mean values were used to calculate for Chi square $\left(X^{2}\right)$, which is listed in Table 2 . This test calculates whether the expected frequency was any where near the observed frequency. Using 95\% confidence level and the degrees of freedom of 1 , the value 3.84 was used to accept or reject the hypothesis. If Chi square values were equal to or below 3.84 the band was accepted as real. Dispersal of three separate runs around the mean was calculated using the equation for standard deviation (SD). The values of SD for each gene are listed below in Table 2. Since the SD and mean come from repeated experiments coefficient of variation (CV) values were calculated. The CV value, which is the SD expressed as a percent of the mean, is a measure of 
Table 2. Collection of all of the statistically significant data for isolate 6 .

\begin{tabular}{|l|c|c|c|c|c|c|}
\hline Gene & Mean & Expected & Chi Square & Standard deviation & Standard error & Coefficient of variation \\
\hline Cry1A & 539 & 522 & 0.554 & 21.4 & 12.3 & $3.97 \%$ \\
Cry2A & 477 & 473 & 0.034 & 17 & 12 & $3.56 \%$ \\
Cry25Aa & 436 & 447 & 0.271 & 12.7 & 7.35 & $2.92 \%$ \\
\hline
\end{tabular}

Table 3. Collection of all of the statistically significant data for isolate 10 .

\begin{tabular}{|l|c|c|c|c|c|c|}
\hline Gene & Mean & Expected & Chi Square & Standard deviation & Standard error & Coefficient of variation \\
\hline Cry1A & 557 & 522 & 2.302 & 20.5 & 11.8 & $3.68 \%$ \\
Cry1l & 449 & 413 & 3.138 & 25.98 & 15 & $5.79 \%$ \\
Cry2A & 507 & 473 & 2.44 & 18.73 & 10.8 & $3.70 \%$ \\
Cry25Aa & 427 & 447 & 0.925 & 5.686 & 3.28 & $1.33 \%$ \\
\hline
\end{tabular}

reliability. Based on the Chi Square values the bands were accepted as real and according to SD, SE and CV these data are reliable.

The three genes that were amplified for Bt6; cry $1 A$, cry2 $A$ and cry25Aal, were cloned and sequenced. They were then aligned using the National Center of Biotechnological Investigation database. The cry $1 \mathrm{~A}$ gene aligned to the $\operatorname{cry} 1 A$ gene on the pUCBtS93 plasmid of $B$. thuringiensis subspecies kurstaki. The cry2A gene aligned to the cry2Ab gene on a plasmid of $B$. thuringiensis. The last gene cry25Aa aligned to the genome of $B$. cereus ATCC 14579.

\section{Crystal gene presence for isolate $\mathbf{1 0}$}

Analysis of the amplified product in isolate 10 was done using the central tendency (mean) values for crystal genes $1 \mathrm{~A}, 1 \mathrm{I}, 2 \mathrm{~A}$, and $25 \mathrm{Aa}$ from isolate 10 . The mean values were used to calculate for Chi square $\left(X^{2}\right)$ which is listed in Table 3. Based on the Chi Square values the bands were accepted as real and according to SD, SE and CV these data are reliable.

These four genes that amplified for Bt10; cry1A, cry1l, cry2A and cry25Aa, were cloned and sequenced. The cry $1 A$ gene aligned to the cry $1 A c$ gene of $B$. thuringiensis. The cry1l gene also aligned to the cry1l gene of $B$. thuringiensis. The cry2A gene aligned to the cry2Ab gene on a plasmid of $B$. thuringiensis. The last gene cry25Aa aligned to the genome of $B$. cereus ATCC 14579.

\section{Crystal gene location}

PFGE analysis suggests that isolates 6 and 10 has 45 and $49 \mathrm{~kb}$ fragments, respectively (Figure 1). Not all the

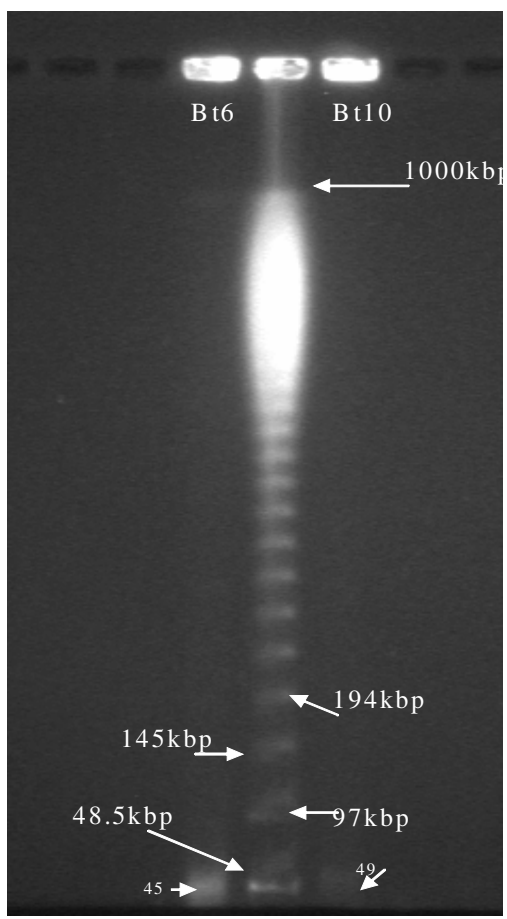

Figure 1. PFGE analysis of isolates 6 and 10. A Lambda ladder standard was used with fragments ranging from 48.5 to $1000 \mathrm{~kb}$. This figure suggests that isolates 6 and 10 has 45 and $49 \mathrm{~kb}$ fragments, respectively

expected crystal genes resided on that $50 \mathrm{~kb}$ fragment. Out of the expected genes that amplified previously, only cry1A amplified in isolates 6 and10 (Figure 2). Larger fragment like $1944 \mathrm{~kb}$ fragment remained in the wells of the pulsed field gel along with the genomic DNA. These larger fragments that remained were also excised, purified, hybridized and amplified. Along with cry1 A being 


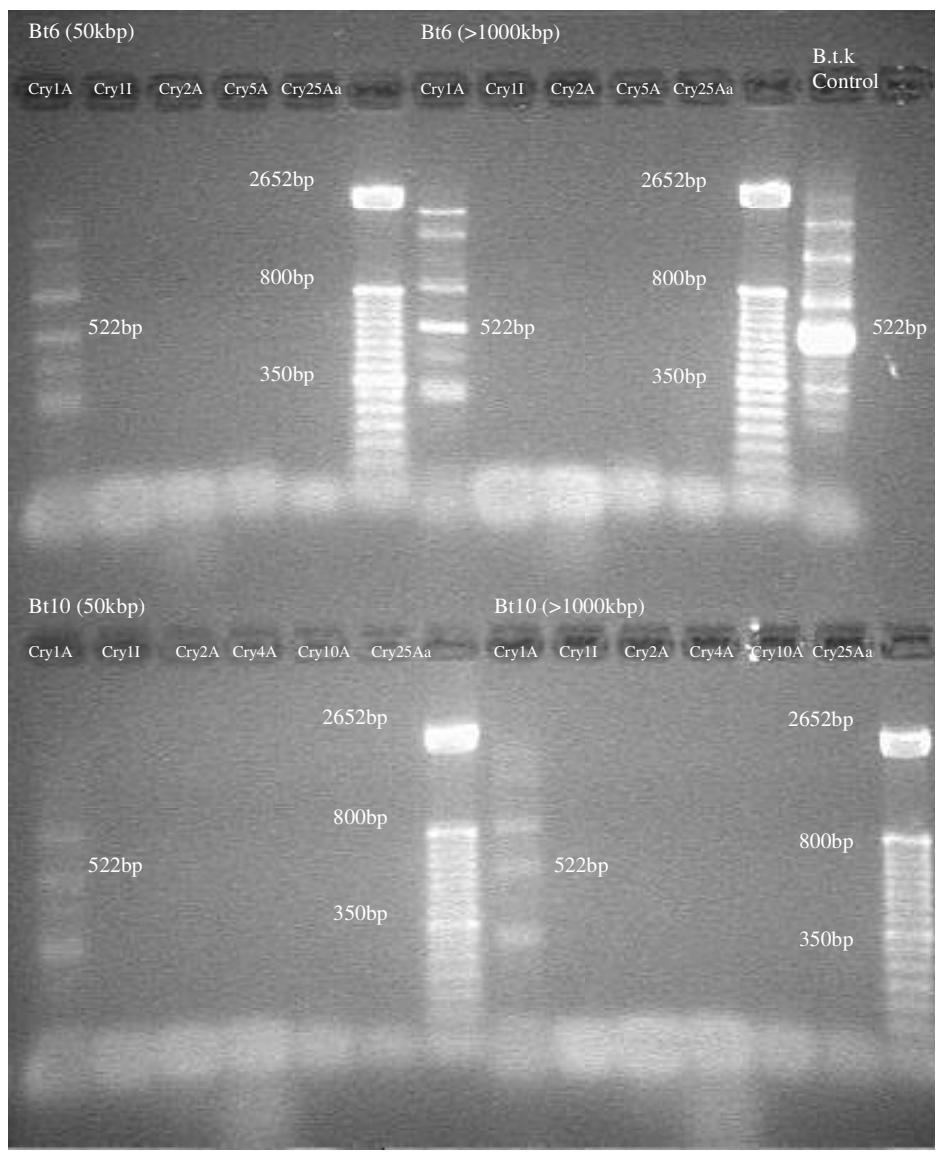

Figure 2. Amplified products for isolates 6 and 10. The 50 and $>1000 \mathrm{~kb}$ row is the fragment that was excised out of the pulsed gel.

found in the $50 \mathrm{~kb}$ fragment, Figure 2 also shows that cry $1 \mathrm{~A}$ is located in a fragment larger than $1000 \mathrm{~kb}$ for isolates 6 and 10.

\section{DISCUSSION}

Based on earlier work, $B$. thuringiensis was observed to have several extra-chromosomal elements besides it genomic DNA (Carlson et al., 94). These extrachromosomal elements or so called plasmids have been linked to $\delta$-endotoxin genes through homologous studies (Carlson and Kolsto, 1993). Through the utilization of PFGE several DNA fragments were obtained and can be eluted from a single bacterial colony. Typically, chromosomal sized DNA is resolved (Schwartz and Cantor, 1984) but other fragments ranging in size: less than $50 \mathrm{~kb}$ (small), $50-300 \mathrm{~kb}$ (medium), 300-800 kb (large), and $600-2500 \mathrm{~kb}$ (very large) can also be resolved. The different sized fragments can be separated just by changing a few variables within the design of the pulsed field program. The specific type of PFGE used in our experiment to separate out plasmids from $B$. thuringiensis was the contour-clamped homogeneous electric field (CHEF) (Chu et al., 1986, 1990).

Previous workers have shown that most of the $\delta$ endotoxin genes are linked to movable extrachromosomal fragments (plasmid) (Gonzalez et al., 1981; Debabov et al., 1977; Gonzalez and Carlton, 1980; Stahly et al., 1978) and even some probes have hybridized to the genomic fragment (Carlson and Kolsto, 1993). More importantly Gonzalez suggested that these crystal genes were not just located on plasmids but they were located on large plasmids. A $1944 \mathrm{~kb}$ plasmid existed in $B$. thuringiensis israelensis which contains $\delta$ endotoxin genes responsible for crystal protein production (Gonzalez and Carton, 1984; Ward and Ellar, 1983). More recent studies in $B$. thuringiensis strain $\mathrm{H} 1.1$ shows that even a smaller plasmid can carry the crystal gene. This smaller plasmid named pG13 was reported as being 11,365 bp in size (Hoflack et al., 1997).

Most researchers working with $B$. thuringiensis utilize restriction enzymes like Notl and Smal to cut the genome into fragments allowing for accurate typing of the organism (Swiecicka, 2003; Gaviria Rivera 2003). Restriction digestion in combination with PFGE has been 
accepted as an accurate and reproducible method for typing of clinically relevant bacteria (Tenover, 1995) for over a decade.

By not utilizing restriction enzymes we felt we could possibly isolate the actual intact extra-chromosomal fragment which would allow for better profiling of the plasmids. Isolates 6 and 10 both revealed extrachromosomal fragments when this adapted method was used. This is consistent with previous studies suggesting that $B$. thuringiensis subspecies have extra-chromosomal fragments. Once these fragments were purified, it revealed that the small fragments from isolates 6 and 10 contained cry $1 \mathrm{~A}$ gene based on additional hybridization studies. cry $1 \mathrm{~A}$ also was also present in the fragments that remained in the wells of the pulsed gel in both isolates. This suggests that cry $1 \mathrm{~A}$ is both on a smaller extra-chromosomal fragments as well as on a larger than $1000 \mathrm{~kb}$ fragment. The cry $1 A$ gene is, thus, a ubiquitous gene. A possible explanation for this abundance could probably be because of the transposable regions that flank both sides of the cry1 gene (Kronstad and Whiteley, 1984; Lereclus et al., 1984).

\section{REFERENCE}

Carlson C, Kolstø AB (1993). A complete physical map of a Bacillus thuringiensis chromosome J. Bacteriol. 175: 1053-1060.

Carlson C, Caugant D, Kolstø AB (1994). Genotypic diversity among Bacillus cereus and Bacillus thuringiensis strains, Appl. Environ. Microbiol. 60: 1719-1725.

Chu G, Vollrath D, Davis R (1986). Separation of large DNA molecules by contour-clamped homogenous electric fields. Science 234: 15821585.

Chu G (1990). Pulsed-field electrophoresis: theory and practice. In Methods: A Companion to Methods of Enzymology. Pulsed-Field Electrophoresis (B. Birren and E. Lai, eds.)Vol.1, No.2, pp. 129-142. Academic Press, San Diego.

Crickmore N, Zeigler D, Feitelson J, Schnepf E, Van Rie J, Lereclus D, Baum J, Dean D (1998). Revision of the nomenclature for the Bacillus thuringiensis pesticidal crystal proteins Microbiol. Mol. Biol. Rev. 62: 807-813.

Crickmore N, Zeigler D, Schnepf E, Van Rie J, Lereclus D, Baum J, Bravo A, Dean D (2002). "Bacillus thuringiensis toxin nomenclature" http://www.biols.susx.ac.uk/Home/Neil_Crickmore/Bt/index.html

Debabov V, Azizbekyan R, Kleballina O, D'yachenko V, Galushka F, Belykh R (1977). Isolation and preliminary characteristics of extrachromosomal elements of Bacillus thuringiensis DNA, Genetika 13: 496-501.

Ejiofor A, Johnson T (2002). Physiological and molecular detection of crystalliferous Bacillus thuringiensis strains from habitats in the South Central United States, J. Industrial Microbiol. Biotech. 28: 284-290.

Gaviria Rivera A, Priest F (2003). Pulsed field gel electrophoresis of chromosomal DNA reveals a clonal population structure to Bacillus thuringiensis that relates in general to crystal protein gene content, FEMS Microbiol. Lett. 223: 61-66.
Gonzalez Jr. J, Carton B (1980). Patterns of plasmid DNA in crystalliferous and acrystalliferous strains of Bacillus thuringiensis, Plasmid 3: 92-98.

Gonzalez Jr. J, Carton B (1984). A large transmissible plasmid is required for crystal toxin production in Bacillus thuringiensis var. israelensis, Plasmid 11: 28-38.

Gonzalez Jr. J, Brown B, Carton B (1981). Correlation between specific plasmids and $\delta$-endotoxin production in Bacillus thuringiensis, Plasmid 5: 351-365.

Grochulski P, Masson L, Borisova S, Pusztai-Carey M, Schwartz J, Brousseau R, Cygler M (1995). Bacillus thuringiensis CrylA(a) insecticidal toxin: crystal structure and channel formation. J. Mol. Biol. 254: 447-464.

Hoflack L, Seurinck J, Mahillon J (1997). Nucleotide sequence and characterization of the cryptic Bacillus thuringiensis plasmid pG13 reveal a new family of rolling circle replicons J. Bacteriol. 179: 50005008.

Höfte H, Whiteley H (1989). Insecticidal crystal proteins of Bacillus thuringiensi., Microbiol. Rev. 53: 242-255.

Kronstad J, Whiteley H (1984). Inverted repeat sequences flank a Bacillus thuringiensis crystal protein gene. J. Bacteriol. 160: 95-102.

Lecadet M, Frachon E, Cosmao Dumanoir V, Ripouteau H, Hamon S, Laurent P, Thiery I (1999). Updating the $\mathrm{H}$-antigen classification of Bacillus thuringiensis. J. Appl. Microbiol. 86: 660-672.

Lereclus D, Ribier J, Klier A, Menou G, Lecadet M (1984). A transposon-like structure related to the $\delta$-endotoxin gene of Bacillus thuringiensis. EMBO J. 3: 2561-2567.

Li J, Carroll J, Ellar D (1991). Crystal structure of insecticidal $\delta$ endotoxin from Bacillus thuringiensis at 2.5å resolution, Nature 353: 815-821.

McEllistrem M, Stout J, Harrison L (2000). Simplified Protocol for PulseField Gel Elecrophoresis Analysis of Streptococcus pneumoniae, J. Clin. Micr. 38: 351-353.

Ohba M, Alzawa K (1978). Serological identification of Bacillus thuringiensis and related bacteria isolate in Japan, J. Invertebr. Pathol. 32: 303-309.

Sambrook J, Fritsch E, Maniatis T (1989). Molecular Cloning: A Laboratory Manual $2^{\text {nd }}$ ed. Cold Spring Harbor, New York, pp 1.211.52.

Schwartz D, Cantor C (1984). Separation of yeast chromosome-sized DNAs by pulsed field gradient gel electrophoresis, Cell 37: 67-75.

Stahly D, Dingman D, Bulla Jr. L, Aronson A (1978). Possible origin and function of the parasporal crystals in Bacillus thuringiensis, Biochem. Biophys. Res. Commun. 84: 581-588.

Swiecicka I (2003). Molecular typing by pulsed-field gel electrophoresis of Bacillus thuringiensis from root voles, Curr. Microbiol. 46: 256-260.

Travers R, Martin P, Reichelderfer C (1987). Selective process for efficient isolation of soil Bacillus spp., Appl. Environ. Microbiol. 53: 1263-1266.

Tenover F, Arbeit R, Goering R, Mickelson P, Murray B, Persing D, Swaminathan B (1995). Interpreting chromosomal DNA restriction patterns produced by pulsed-field gel electrophoresis: criteria for bacterial typing, J. Clin. Microbiol. 33 2233-2239.

Ward E, Ellar D (1983). Assignment of the $\delta$-endotoxin gene of Bacillus thuringiensis var. israelensis to a specific plasmid by curing analysis. FEBS Lett. 158: 45-49.

Whalon, McGaughey (1998). Bacillus thuringiensis: Use and Resistance management. In: Insecticides with novel modes of action: mechanism and application, Ishaaya I, Degheele D, Eds. Springer, Berlin. pp. 106 -137 . 